\title{
INCIDENCE OF LIVER FLUKES AND GASTRO-INTESTINAL PARASITES IN CATTLE
}

\author{
S. A. $\operatorname{Sardar}^{1}$, M. A. $\operatorname{Ehsan}^{* 2}$, A. K. M. M. Anower ${ }^{3}$, M. M. Rahman ${ }^{4}$ and M. A. Islam ${ }^{5}$ \\ ${ }^{2}$ Department of Medicine, Faculty of Veterinary Science, Bangladesh Agricultural University, Mymensingh- \\ 2202, Bangladesh \\ *Corresponding author : maehsan2003@yahoo.com
}

\begin{abstract}
The prevalence and seasonal variation in liver fluke and gastro-intestinal parasites were studied in native $(\mathrm{n}=360)$ and crossbred $(\mathrm{n}=360)$ cattle with four age groups ( $<12$ months, $>12-24$ months, $>24-36$ months and $>36$ months) and three seasons (summer, rainy and winter) in Trishal Upazilla, Mymensingh district for a period of November 2002 to October 2003. Feces were collected to examine the worm load in each of the animal. The maximum rate of infection of gastrointestinal parasite was recorded in crossbred cattle with the exception of Strongylid. In the rainy season highest gastrointestinal parasitic infestation was observed. The infection rates of Fasciola, Paramphistomum, Trichuris and Schistosoma were highest in the age group $>36$ months and lowest in the age group $<12$ months. The infection rates of Ascaris, Strongylid, Strongyloids and Moniezia were very high in the age group $<12$ months and low in the age group $>36$ months.
\end{abstract}

Key words: Incidence, liver fluke, gastro-intestinal parasites, native and crossbred cattle

\section{INTRODUCTION}

Gastro-intestinal parasites are problems among cattle population in Bangladesh. The infection rates are variable depending upon different intrinsic and extrinsic epidemiological and biological factors. The economic losses may be in the form of mortality, decreased productivity, reduced weight gain and other means resulting globally from parasitic diseases. Most cattle population in Bangladesh comes from primitive and low productive breeds. Most animals are reared in house under the age old traditional husbandry practices. Many cattle are over worked and most of them under fed or half fed during most of the time of the years. They are not supplied with adequate balanced ration. As a result the general nutritional status of most of the cattle is in subnormal level, which greatly increases susceptibility to parasitic diseases (Blood et al., 1990). The temperature, humidity and rainfall of the country are highly fevourable for parasites.

In this country a limited number of studies on some epidemiological aspects of different gastro-intestinal parasites have been carried out by Islam et al. (1971), Rahman and Razzak (1973), Rahman and Ahmed (1991), in indigenous breed of cattle. For this reason the present study has been undertaken in Trishal Upazilla of Mymensingh District with the following objectives: to find out the prevalence and seasonal variation of various flukes and gastro-intestinal parasite infections in native and crossbred cattle.

\section{MATERIALS AND METHODS}

The study was conducted with 360 native and 360 crossbred cattle selected randomly from six villages in Trishal Upazilla of Mymensingh District for a period of November 2002 to October 2003. There are about 33601 hectors lands in this Upazilla. Most of the cattle in this area are reared by farmers at their homestead and are managed under the rural husbandry practice. A cross sectional study was designed which was performed in three seasons on randomly selected samples of animal.

Present address: ${ }^{1}$ Central Veterinary Hospital, Dhaka, ${ }^{3}$ Department of Microbiology, Barishal Govt. Veterinary College, Barishal, ${ }^{4}$ District Veterinary Hospital, Gazipur, ${ }^{5}$ Fulgazi Veterinary Hospital, Feni, Bangladesh. 
The breed characteristics were determined by inspecting the phenotyping characters of the animal or by carefully questioning the owner and from the record of A.I. register. In this study the animal was grouped into two groups namely native and crossbred. One year study period was divided into three seasons namely Summer (March to May), Rainy (June to October) and Winter (November to February). In this study the animals were grouped into four according to age. The age of animals of groups A, B, C and D were up to 12 months, > 12 months to 24 months, > 24 months to 36 months and > 36 months respectively.

About $15 \mathrm{gm}$ fecal materials were collected from each of the selected animals directly from the rectum or from freshly voided feces in polythene bags. The sample was shifted to the veterinary hospital of Trishal Upazilla where it was stored in the refrigerator and was examined within 2-6 hours. At first the samples were examined for parasitic ova using direct smear method. If three smears were negative, then the case was considered negative in the study. Then from positive cases the numbers of eggs were counted by using "Modified Stoll's Dilution Technique". $3 \mathrm{~g}$ of feces were mixed well and put in $100 \mathrm{ml}$ beaker containing $42 \mathrm{ml}$ of water, some glass beads were added to it. Then it was thoroughly mixed with stirrer. $0.15 \mathrm{ml}$ was taken by $01 \mathrm{ml}$ syringe and put on glass slide and covered with cover slip. The slide was placed under microscope and examined.

The eggs were identified on the basis of morphological features described by Soulsby (1982) and counted. The counts were made from each sample and the mean of it was considered as EPG (Eggs per gram of feces). From positive cases $30 \%$ samples were selected randomly and total EPG were determinated.

At the end of the study period the result were scrutinized and family analyzed commensurations with the objectives.

\section{RESULTS AND DISCUSSION}

The prevalence of parasitic infestations between native and crossbred cattle is presented in Table 1 . The overall prevalence of gastro-intestinal parasites of crossbred cattle was higher than that of native bred except Strongylid. The rate was almost similar in native and crossbred cattle in respect of Strongyloids. Ross et al. (1959) reported that the Bos indicus are more resistant to parasites than Bos taurus. Haque (1986) also reported that the gastro-intestinal parasitic infestation rate was higher in crossbred cattle.

Table 1. Overall prevalence of different gastro-intestinal parasites in native and crossbred cattle as observed by faecal examinations

\begin{tabular}{|lllllllll|}
\hline Breed & \multicolumn{1}{l}{ Number of cases (\%) } \\
\cline { 2 - 8 } & \multicolumn{1}{l}{ Fasciola } & Paramphistomum & Ascaris & Strongylid & Strongyloides & Trichuris & Schistosoma Moneizia \\
\hline $\begin{array}{l}\text { Native } \\
(\mathrm{n}=360)\end{array}$ & 90 & 163 & 62 & 88 & 32 & 22 & 106 & 30 \\
$\begin{array}{l}\text { Cross } \\
(\mathrm{n}=360)\end{array}$ & $(45.28)$ & $(17.22)$ & $(24.44)$ & $(8.89)$ & $(6.11)$ & $(29.44)$ & $(8.33)$ \\
& $(30.56)$ & $(51.11)$ & $(21.67)$ & $(24.74)$ & $(9.17)$ & $(8.61)$ & $(37.78)$ & $(9.44)$ \\
\hline
\end{tabular}

$\mathrm{n}=$ Number of animals examined.

The age wise prevalence rate of different gastro-intestinal parasites between native and crossbred cattle are presented in Table 2. In the table the infection rates of Ascaris, Strongylid and Strongyloids were very high in the young animals starting from the age group of $<12$ months and gradually declined. In the age group $>24-36$ months and $>36$ months the infection rates were very much and the rates were almost similar in both native and crossbred cattle. Overend et al. (1984) reported same findings. The infection rate of Fasciola, Paramphistomum and Schistosoma were highest in the age group of $>36$ months. The increase in prevalence of these parasites with the age has been reported by Rahman and Mondol (1983). In the present study it was observed that prevalence increased with age in a linear pattern. 
Incidence of parasites in cattle

Table 2. Age wise prevalence rates of different gastro-intestinal parasites in native and crossbred cattle as observed by faecal examination

\begin{tabular}{|c|c|c|c|c|c|c|c|c|c|}
\hline \multirow{2}{*}{$\begin{array}{l}\text { Age of } \\
\text { animal } \\
\text { (Months) }\end{array}$} & \multirow{2}{*}{$\begin{array}{l}\text { Breed } \\
(\mathrm{n}=90)\end{array}$} & \multicolumn{8}{|c|}{ Number of cases (\%) } \\
\hline & & Fasciola & $\begin{array}{l}\text { Paramphis- } \\
\text { tomum }\end{array}$ & Ascaris & Strongylid & Strongyloides & Trichuris & Schistosoma & Moneizia \\
\hline \multirow[t]{2}{*}{ Up to 12} & Native & $0 \varepsilon$ & $15(16.66)$ & 34 (37.77) & 30 (33.33) & 14 (15.55) & $05(5.55)$ & $15(1$ & $11(12.22)$ \\
\hline & Cross & $10(11.11)$ & $16(17.77)$ & 48 (53.33) & 39 (43.33) & 15 (16.66) & 05 (5.55) & $22(24.44)$ & 11 (12.22) \\
\hline \multirow[t]{2}{*}{$>12$ to 24} & Native & $18(20)$ & $28(31.11)$ & $20(22.22)$ & 25 (27.77) & $11(12.22)$ & $06(6.66)$ & $23(25.55)$ & $10(11$. \\
\hline & Cross & $24(26.66)$ & 35 (38.88) & $21(23.33)$ & $28(31.11)$ & 12 (13.33) & 07 (7.77) & $33(36.66)$ & 09 (10) \\
\hline \multirow[t]{2}{*}{$>24$ to 36} & Native & 30 (33.33) & 57 (63.33) & $08(8.88)$ & $17(18.88)$ & $04(4.44)$ & $06(6.66)$ & $34(37.77)$ & $05(5.55)$ \\
\hline & Cross & 37 (41.11) & $65(72.22)$ & $09(10)$ & $11(12.22)$ & 03 (3.33) & $09(10)$ & $40(44.44)$ & 06 (6.66) \\
\hline \multirow[t]{2}{*}{$>36$} & Native & 34 (37.77) & $59(65.55)$ & $00(0$. & $16(17.77)$ & $03(3$. & $06(6.66)$ & $34(37.77)$ & $04(4.44)$ \\
\hline & Cross & 39 (43.33) & 68 (75.55) & $00(0.00)$ & $11(12.22)$ & 03 (3.33) & $10(11.11)$ & $40(44.44)$ & $08(8.88)$ \\
\hline
\end{tabular}

$\mathrm{n}=$ Number of animals examined.

Season wise prevalence rates of different parasitic infections are presented in the Table 3 . The highest prevalence rates of different parasites were observed in the rainy season (July to October) except in case of Ascaris. The infection rate of Ascaris was highest in winter. The present study correlated with the findings of the Eysker and Ogunsusi (1980). The high rate of infection in rainy season is quite reasonable. Because during this time the rainfall is abundant and there is abundance of intermediate hosts of Fasciola and Paramphistomum. The temperature and humidity become optimum for larval development of parasites in this season and are favourable for the migration and development of infective stage in snails.

Table 3. Season wise prevalence rates of different gastro-intestinal parasites in native and crossbred cattle as observed by faecal examination

\begin{tabular}{|llllllllll|}
\hline Season & $\begin{array}{l}\text { Breed } \\
(\mathrm{n}=90)\end{array}$ & \multicolumn{2}{l}{ Number of cases (\%) } \\
\cline { 3 - 9 } & & Fasciola & $\begin{array}{l}\text { Paramphis- Ascaris } \\
\text { tomum }\end{array}$ & Strongylid & Strongyloides Trichuris & Schistosoma & Moneizia \\
\hline Winter & Native & $26(21.66)$ & $50(41.66)$ & $26(21.66)$ & $26(21.66)$ & $11(9.16)$ & $06(5.00)$ & $30(25)$ & $07(5.83)$ \\
& Cross & $31(25.83)$ & $56(46.66)$ & $31(25.83)$ & $28(23.33)$ & $09(7.50)$ & $08(6.66)$ & $39(32.50)$ & $10(8.33)$ \\
Summer & Native & $29(24.16)$ & $54(45)$ & $16(13.33)$ & $31(25.83)$ & $11(9.16)$ & $07(5.83)$ & $37(30.83)$ & $11(9.16)$ \\
& Cross & $39(32.50)$ & $64(53.33)$ & $25(20.83)$ & $30(25)$ & $12(10)$ & $11(9.16)$ & $48(40)$ & $12(10)$ \\
Rainy & Native & $35(29.16)$ & $59(49.16)$ & $20(16.66)$ & $31(25.83)$ & $10(8.33)$ & $09(7.50)$ & $39(32.50)$ & $12(10)$ \\
& Cross & $40(33.33)$ & $64(53.33)$ & $22(18.33)$ & $31(25.83)$ & $12(10)$ & $12(10)$ & $49(40.83)$ & $12(10)$ \\
\hline
\end{tabular}

Winter = November to February, Summer $=$ March to May and Rainy $=$ June to October

The maximum rate of infection of gastro-intestinal parasite was recorded in crossbred cattle with the exception of Strongylid. In the rainy season the highest gastro-intestinal parasitic infestation was observed. The infection rates of Fasciola, Paramphistomum, Trichuris and Schistosoma were highest in the age group > 36 months and lowest in age group $<12$ months. 


\section{REFERENCES}

1. Blood DC, Radostits OM, Henderson JA, Arundel JH and Gay CC (1990). Veterinary Medicine. $7^{\text {th }}$ edn., The English Language Book Society and Bailliere Tindall.

2. Eysker M and Ogunsusi RA (1980). Observation on epidemiological and clinical aspects of gastro-intestinal helminthiasis of sheep in Northern Nigeria during rainy season. Research in Veterinary Science 28: 58-62.

3. Haque MA (1986). Effects of sex, age, breed, season and system of management in the infectivity of gastro-intestinal parasitism in cattle. A thesis submitted to the Dept. of Medicine, Faculty of Veterinary Science, BAU, Mymensingh.

4. Islam KS, Shaikh H and Soliman KN (1971). Occurrence of visceral Schistosomiasis of cattle and goats in East Pakistan. Proc. Pakistan Science Conference, University of Peshwar. P. 16.

5. Overend D, Veale PI and Copeland JW (1984). An epidemiological study of Trichostrongylidiasis in dairy cattle grazing in irrigated pasture. Australian Veterinary Journal 61: 6-8.

6. Rahman MF and Ahmed Z (1991). Final report of "Pilot project for the control of parasitic disease of animals in Bangladesh”, Bangladesh Livestock Research Institute, Dhaka.

7. $\quad$ Rahman MH and Mondol MH (1983). Helminth parasites of cattle (Bos indicus) in Bangladesh. Indian Parasitology 7: 173-174.

8. Rahman MH and Razzak A (1973). Incidence of helminth parasites infecting cattle in the Kotowali Thana of Comilla. First Bangladesh Veterinary Conference. BAU, Mymensingh. P-25.

9. Ross JG, Lee RP and Armour J (1959). Haemonchosis in Nigerian Zebu Cattle: The influence of genetic factors in resistance. Veterinary Record 71: 27-31.

10. Soulsby EJL (1982). Helminths, Arthropods and Protozoa of Domestic Animals. $7^{\text {th }}$ edn., The English Language Book Society and Bailliere Tindall. 